\title{
Youth in View of the Issue of School Violence
}

\author{
Malgorzata Dubis (PhD) \\ WSEI Lublin, Poland \\ Jolanta Karbowniczek (Associate Professor) \\ IgnatianumAcademyCracow, Poland
}

Doi: 10.19044/esj.2018.v14n8p70 URL:http://dx.doi.org/10.19044/esj.2018.v14n8p70

\begin{abstract}
Violence and aggression has become common phenomena in modern world, they include almost all fields of social life. The reflection of problems the society copes with, is visible in the way of perceiving the educational values by pupils and their behaviour at school. The nature of the educational process organised by school is mainly the interactions among teachers and pupils and pupils themselves. They are not always the best. The anxiety among guidance counsellors and psychologists raises the fact that the cooperation rule and mutual help are replaced by the rule of dominance, extortion and force. The cases of ignoring the teacher's orders are more and more common, lack of respect towards the teaching staff, humiliating adults and vandalism. Pupils battle against teachers and peers too. The school hall is a kind of arena of undesirable behaviours.

Therefore, the school as an institution in which children and young people spend $1 / 3$ of their time during the day, should not only deal with teaching but take an active part in the implementation of activities in the field of broadly understood prevention and upbringing. Therefore there are challenges in front of the school aiming at stopping, limiting or even eliminating negative behaviours from children's and teenagers' lives.
\end{abstract}

Keywords: Youth, school, aggression, violence, bullying

\section{Introduction}

Contemporary youth is a generation that is not only one of the most important social categories, but also an "important actor" of social life. Therefore, it is a constant object of interest of representatives of various research disciplines. Special interest in youth is visible when social changes occur. In this case, the youth is a sensitive tool that allows to observe the upcoming changes. In addition, it is youth that is assigned to an important place in the process of social change, treating it as an innovative factor, hidden 
reserve and potential that can be used in the processes of change (Mannheim, 2011). As P. Peret - Drazewska emphasizes, it is the young people that is "the source of prospective developmental changes, bringing dynamics, vitality and «freshness»of views to a society, is the driving force for development, which protects social life from stagnation" (2014, p. 68).

Being young is a special period in a person's life. The natural predispositions of a young person associated with changes occurring in the period of adolescence are also associated with the search for the truth and ideals of own "me". A young man posed to reality asks about norms and values. Among many values that he meets every day, he looks for those that will give him confidence that he can build his life sensibly (Dubis, Karbowniczek 2015).

Today's youth largely reflects the condition of adults in our society. Juveniles often reflect inadequate, unacceptable behaviours of today's adults, modellingpatterns derived from their own family (Karbowniczek 2012). In addition, the contemporary world is dominated by the media, which not only provide entertainment, but also create interpersonal relationships, interests, aesthetic tastes, and also influence the choices of attitudes towards reality. A young man who participates in the "nice" vision of the world created by the media, becomes more impatient, distracted, loses the ability to focus (Karbowniczek 2011). This "love" of immediacy, the "now" that the media teaches, bombarding with information about acts of violence, crimes, rape, banditry, terrorism, disasters and accidents makes it difficult for a young man to clearly distinguish between good and evil, truth from falsehood. Therefore, violence and aggression have become common phenomena, covering almost all areas of social life. A young man, observing these events, may become convinced that in the modern world everything can be achieved and settled by force, violence, aggression.

Young people learn aggression, as well as other behaviours not only on the basis of their own experience, but also through observation of the behaviour of other people and perceiving the consequences to which it leads. The presence in the wide spectrum of various types of aggressive behaviours is a significant social problem, especially in the case of their occurrence among children and adolescents.

The increase in aggressive behaviour within the school area is confirmed by daily observations of teachers and parents, as well as social studies and police statistics. Not only the growing of various forms of aggression and violence among young people is disturbing, but the brutalization of such activities (Dubis 2012). Due to its common character and function, the school is the area where almost all forms of negative behaviour are revealed in varying degrees and in various forms. 


\section{Definition and interpretational problems of concepts: aggression, violence}

In Polish schools aggressive behaviour is a well-known phenomenon. However, directors and teachers are not interested in publicizing the disturbing phenomena in their institutions, fearing that the media will inform the public about the shocking events such as: beating children, teachers, extortion among students, etc. This is unfavourable because it involves lowering the school's rank, which could be described as dangerous. This situation often leads to a kind of duality: directors, teachers treat violence defensively: with embarrassment, shame, helplessness, tendency to hide facts, and journalists reveal it drastically, often indicating school as the main reason for this situation (Dubis 2010).

In the literature on the subject, one can meet the multifaceted and complexity of the definition of aggression and violence. W. Okon (2017) and A. Fraczek (1996) emphasize that these are actions taken intentionally, directed against people or objects and causing pain, suffering, destruction, leading to the loss of valued values.

Nowadays, aggression is most often defined as a conscious and intentional hostile behaviour that is directed against people or objects with the intention of causing harm, damage, loss or pain (Surzykiewicz 2000; Danielewska 2002; Kolodziejczyk 2004; Libiszowska - Zoltkowska 2008; Milkowska - Olejniczak 2003). These types of behaviour go beyond social norms, and they are based on negative attitudes or emotions of the perpetrator (Brzezińska 2004).

In pedagogical literature, aggression is understood in two ways: as behaviour undertaken with the intent of causing damage, leading in fact or potentially to negative consequences (pain, suffering, loss of valuable values), but also as an internal emotional state of an individual characterized by irritation, anger, hostility or the will to do harm (Kowal 2012; Krahe 2005). We can therefore speak of instrumental and hostile aggression. The effect of instrumental aggression is harm done to the other person, but it serves as a means to achieve a goal other than causing pain. They are therefore side effects, complementing the act of hostile aggression, understood as expression of feelings. The enemy's aggression is caused by anger and is intended to cause pain or physical injury. The concept of aggression is often associated with the concept of aggressiveness and violence. However, these terms should not be confused. Because aggression is a process, an individual's activity, and aggressiveness is a disposition to react with aggressive behaviour. This is a personality trait, learned behaviour, well-established in the process of social learning. According to J.M. Wolinska (2003) aggressiveness is a constant feature of a man consisting of frequent and inadequate aggressive reactions to 
social objects and inability to control own aggressive reactions. It can occur with various intensities.

A characteristic feature is that an individual responds with emotional stimulation. It can therefore be said that frequent behaviours characterized by inadequate aggressive reactions of a significant intensity are called aggressiveness. However, individual specific behaviours characterized by specific properties are aggressive behaviours that are triggered and controlled by negative emotions (Dubis 2014; Wojciszke 2003).

Ability to aggressive behaviour can be a tool to use violence. Violence is any deliberate act, threatening or actual act that undermines the individual's personal freedom or contributes to a person's physical and mental injury. It is an intentional action that causes injury, suffering and damages to an individual or group (Pospiszyl 1999; Surzykiewicz 2000; Dahleberg, Krug 2002; Szpringer 2004; Guerin 2004; Portman 2006). While aggression belongs to the sphere of emotions, violence belongs to the sphere of rationality. The factor that differentiates between violence and aggression is the strength of one of the parties. In violence, it is always on the side of the perpetrator, in the case of aggression it is considered to be balanced.

The essence of the distinction between violence and aggression is the goal. In the case of violence, suffering is a way to achieve the goal, enslavement of the victim, elimination of its sovereign thoughts and actions, subordination to its tasks and the needs of the perpetrator, for example, forcing specific behaviours. However, the purpose of aggression is to harm the victim, causing physical pain. In addition, aggressive behaviour can be incidental. In turn, violence is usually of a continuous character, characterized by an imbalance between individuals in the field of aggressive behaviour and defence (Dubis 2012). The essence of violence is the conscious use of one's own advantage, strength in order to gain benefits and subordination to the victim.

The constitutive elements of violence are: a specific way of acting and a specific effect caused by this action (Blachut, Gaberle, Krajewski 2006). The group of seven elements constituting the phenomenon of violence makes it easier to diagnose the situation of violence:

- willingness to hurt someone,

- $\quad$ initial willingness to hurt someone put into action,

- $\quad$ experiencing pain by someone experiencing violence,

- $\quad$ violence used by the stronger against the weaker,

- unjustified violence,

- cyclical violence,

- $\quad$ the perpetrator enjoys violent behaviour (Rigby 2002, p. 14). 
Bullying is a particular form of violence - often used as a term for systematic,long - term persecution, humiliation or exclusion from the group of one person by a group of students who consciously use their advantage for this purpose (Dombach 2003; Olweus 2007). In turn, a characteristic feature of mobbing $^{1}$ is that the aggressors unload their anger on the object of violence, which improves their collective well-being. It should be emphasized that the repression of an aggrieved person may last for months or even years. In addition, mobbing is becoming more sophisticated and more dangerous with the age of the child. Nowadays, mobbing involves a particular form of this phenomenon - stalking, consisting in persistent persecution and harassment of another human being with the use of electronic media.

Concluding the above considerations, it should be emphasized that the relationship between the concepts: aggression, violence and bullying is hierarchical. While aggression is the broadest term, violence is a bit narrower, and mobbing, as a character of violence, has the narrowest scope. The above behaviours always break the basic human values, cause strong tensions, emotions and injuries. Therefore, their recognition and differentiation is important, since the possible further action will depend on which of the phenomena we are dealing with.

\section{School as a source of aggressive behaviour}

Aggression and violence are the essence of the so-called "second life" of the school. These are not new phenomena, they have always existed at school, only their forms and frequency of occurrence have changed. Every day the school (class, cloak-room, courtyard etc.) is a place of various behaviours of aggressive or violent character. They become an instrument to achieve the intended goals, both on the part of the student and many times teachers. The normality in a modern school is: calling, bullying, forcing, humiliating, fighting or obscene vocabulary. It is disturbing that students (perpetrators) do not perceive their behaviour as bad. This favours the consolidation of inappropriate patterns leading to changes in the pupils' psyche. These phenomena have become a problem of the functioning of many schools. Previous studies indicate a relatively high rate of aggressive behaviour of students within the school area (Grzywa - Bilikiewicz 2006; Karkowska, Czarnecka 200;, Pakulniewicz 2010; Borzucka - Sitkiewicz 2010; Dubis 2016).

School often becomes a place of revealing aggressive and violent behaviour of students, noticed by teachers. It can also be an element of a multifaceted process of creating and growing undesirable behaviours. There are

${ }^{1}$ The terms "mobbing" and "bullying" overlap. While the concept of bullying is widely used in English-speaking countries, the concept of mobbing has been adopted, among others, in Sweden, Finland, Norway, Germany and Poland. 
also situations where, the abnormalities of the school environment generate aggression in students.

Taking into account the specificity of the school's operation and its internal stakeholders, it is possible to identify areas that contribute to the fact that the school can become a source or be crucial for developing, strengthening or triggering aggressive behaviour among young people. J. Kolodziejczyk includes to this areas:

- factors related to school as an institution and its organization: shift learning, numerous classes, students and teachers anonymity, teaching focused on the teacher and the program, students overloaded with learning and with little varied curricula, forced, many hours of sitting in the benches, especially difficult for younger students, and for those who are hyperactive it is like bordering on the miraculous, lack of pedagogical therapy at school for students with developmental dysfunctions and school failures,

- $\quad$ psychological factors: frustration resulting from lack of good contact with adults or aggression on their part, low self-esteem, combined with a large number of negative messages received from adults, lack of clear and respected rules of school life, inability to constructively resolve conflict situations and cope with anger,

- factors related to teacher-student relations: excessive didactic formalism of teachers, application of didactic pressure, inappropriate way of communicating with students (humiliation, criticism, ridicule, etc.), method of solving disciplinary problems during lessons, inconsistent methods of disciplining students, lack of sufficient control on the part of teachers, creating stressful situations, unfair assessment(2004, p. 14-15).

Among the typical school sources of aggression, there are also: unsatisfactory (poor) academic performance, reduced level of motivation, a slight sense of attachment with the school, frequent cases of truancy and limited aspirations related to a professional career. The individual-personality traits of the student are also indicated as significant, among them we find: reduced level of self-control, impulsiveness, difficulty in concentrating of attention, personality, temperament, hyperactivity, tendency to respond in an aggressive manner, etc. (Ostrowska, Surzykiewicz 2005).

Analysing sources of aggression at school one should mention the failures that students experience during school education: receiving negative or poor grades, inability to perform exercises, lack of homework, lack of freedom to express own opinion, fear of malicious comments. The experience of failure is intensified by the fact of social exposure related to the presence of third parties, i.e. peers that are significant for young people. The above factors can cause tensions, anxieties that frustrate students and result in aggression. 
As emphasized by I. Pufal-Struzik "all aggressive situations, all attempts to exert pressure or humiliate are a frequent source of aggressive behaviour of young people. Youth reacts with aggression to the social situation in which they face disapproval and humiliation. Dissatisfaction with oneself causes aggressive behaviour, audacity, arrogance" (2007, p. 13).

In conclusion, it should be emphasized that aggression is most often caused by these actions, which are a form of control, as well as somehow interfering with the privacy of a young, growing man. Aggressive behaviour of students can be a reaction to what is happening on the school grounds. The chaos, the lack of clear expectations, unfair assessment, incorrect relations and disturbed communication arouse frustration even for well-adapted students. It should be emphasized that many conflicts in the school arise as a result of spontaneous aggression, which is caused by accumulated frustration.

\section{Aggressive and violent behaviour in the school area}

School aggression is related to the antisocial intentions, intimidation of other people and repetitive attacks on the same people. It has three basic elements:

- clearly hostile behaviour, arbitrary, without the pressure of other people, conscious and deliberate, with the intention of causing physical or psychological harm,

- $\quad$ expressing this behaviour lead through subsequent acts of aggression to fear, also in relation to the group not involved in acts of school aggression, - behaviour creating an atmosphere of terror in a group - in a school class or in the whole school, because it is known that these attacks will happen again (Kirwil 2004, p. 9).

The above-mentioned elements co-exist with each other regardless of whether the observed behaviour appears to be sudden, spontaneous or previously thought-out.

Considering aggression and violence in the context of the school, indicate the most common characters:

- $\quad$ physical violence (beating, kicking, pushing, jerking, forcing money, taking objects, destroying someone else's property, etc.),

- verbal and psychological violence - calling, ridiculing, mocking, insulting, bothering,

using threats, spreading gossip and slander, showing indecent gestures, exclusion from the group. This type of behaviour is the most common, the most difficult for the student, and at the same time not easy to capture and prove, 
- $\quad$ student wave - a group persecution of younger students by older students using often sophisticated and violent rituals,

- teachers' wave - excessive requirements, too harsh assessment, bullying students, ridiculing, jeering, insulting their dignity, applying penalties disproportionate to guilt, etc. (Dubis 2012).

On school grounds, the phenomenon of aggression and violence is often related to interpersonal relationships that take place in the school environment. We can talk about relationships: student-student, studentteacher, teacher-student and teacher-teacher. The most overt forms of aggression and violence can be seen in the interactions between students. Relations between students are often characterized by high aggression in verbal communication. Screams, threats, insults and provocations are instrumentally used to achieve their own goals. Among children and adolescents, aggressive behaviour takes the form of quarrels and fights with peers, unjustified complaints, malicious rumours, vindictiveness manifested in relation to peers (Dubis 2014). Therefore, aggressive behaviour of students is the everyday life of the school. Research in this area leaves no illusions. Over $76 \%$ of adolescents admit to contact with aggression, and over $68 \%$ indicate more than one type of aggression, of which they were victims or observers (Grzywa - Bilkiewicz 2006).

Similarly, research undertaken by M. Libiszowska-Zoltkowska (2008) show that about $75 \%$ of the students surveyed in Poland personally experience violence in school, i.e. they were either their perpetrator, victim or observer. Only $20 \%$ of the surveyed students were classified as "non-aggressive", while over $22 \%$ were incidentally aggressive (1-2 incidents a year), more than $50 \%$ quite often or often aggressive (from 3 to 16 acts of aggression in a year), and almost $5 \%$ are aggressively notorious students (from 17 to 41 acts of aggression in a year). It is estimated that $20 \%$ to $70 \%$ of students experience bullying at school.

For more than half of the student population, "the school is a source of negative experiences related to the violation of personal dignity, physical persecution, taking things away, extorting tribute, psychological abuse (Dabrowska - Bak, Pawelek 2014, p. 49).

The biggest problem of the students at school is not beating but longlasting ridicule and mockery, forcing peers to specific behaviour. About $10 \%$ of Polish students are systematically tormented. Tormented students experience this type of violence from their colleagues most often several times a month $(42 \%)$, or several times a week $(39 \%)$. For every fifth victim it is a nightmare of everyday life (Przewlocka 2015). It is disturbing that sometimes the class mobbing is favoured by the teacher, showing dislike of 
the pupil having problems at school, making fun of his statements, using offensive terms or nicknames.

It should be pointed out that various forms of violence co-exist with each other. The vast majority of people tormented by peers experienced physical and psychological violence, while in almost half of the cases of people who experienced unwanted touch from their peers also experienced violence in the relationship. There is a noticeable difference in the area of peer violence based on gender. Boys more often (48\%) than girls $(34 \%)$ were victims of mass violence ( $23 \%$ and $12 \%$ respectively), abuse (respectively: $12 \%$ and $9 \%)$ and violence during a date (16\%, 3\% respectively) ). In contrast, touching the intimate parts of the body is more often experienced by girls than boys (respectively: 3.6\% and 1.3\%) (Makaruk 2017). In addition to the above mentioned, there are also such extreme forms of school aggression as: threatening and using dangerous tools (knife, gas, pistol), beating the teacher, sexual aggression (Gilkowska - Olejniczak 2003, p. 40).

On school grounds, aggressive behaviours expressed in verbal form towards teachers (around 50\%) are also widespread. These are the most frequently:lesson interruptions, coarse vocabulary, cheating (Danielewska 2007).

The teacher's aggression towards pupils is a hidden problem. The literature of the subject provides numerous studies indicating that the primary way for the teacher to influence the student is the use of both psychological and physical violence. $70 \%$ of teachers admit to using repressions against pupils. During the lessons, they apply a penalty on average every 5-10 minutes (Dabrowska - Bak 1987; Danielewska 2002; Schneider 1997).

The research of the Helsinki Foundation for Human Rights shows that almost $60 \%$ of students experienced "psychological violence" on the part of teachers, and $31 \%$ of students experienced physical violence at least one time" (Czyz 1997, p. 76-77). At the same time, rural school teachers most often use repression in the form of fisticuffs and insults. On the other hand, teachers working in municipal schools demonstrate power combined with malicious didactic pressure and cause a high level of fear among pupils (Danielewska 2002).

G. Milkowska - Olejniczak's research (2003) also points to instances of aggressive acts on the part of teachers. These are most often: striking student, humiliation, throwing out of the classroom, pulling at the ears, ridiculing.

Polish students who witness violent actions take different attitudes towards the situation. About $40 \%$ of pupils took a passive attitude, observing the course of events and not responding, explaining it with fear and the statement that "everyone has to manage alone". About $49 \%$ of witnesses of 
violence adopted the attitude of a defender of a victim of violence (Komendant - Brodowska, Giza - Poleszuk, Baczko - Dombi 2011).

Asking junior high school students about their attitude to school violence E. Moczuk proves that "violence at school is condemned by $53 \%$ of surveyed students. For $15.9 \%$ of respondents it is an indifferent phenomenon, and $5.9 \%$ of respondents believe that violence is part of the school's life and should not be condemned"' (2015, p. 15).

Also, the authors' own research indicates the existence of aggression and violence at school.

\section{Research methodology and research sample}

Due to the research actions of diagnostic nature, the diagnostic survey was taken as a main method of material gathering and organising research. As a basic tool, the original questionnaire for a student was used. The complement of the questionnaire were the interviews with students. The form of interview was used in presented research, as oriented, open questions, and it allowed for gaining detailed information on the scale of aggression and its main manifestations

The study involved the collection of empirical material and was of a pilot character, conducted in 3 large cities in the Rzeszów Region: 3 mediumsize towns, 3 small towns, and 3 rural environments, by the method of targeted and random multi-stage sampling. The sample was selected using the following requirements: all the respondents attended junior high school; into the study were randomly classified one first, second and third-grade class from each school in each location; therefore, performing a stratified sampling.

The study covered 283 adolescents attending grades 1-3, including: 96 adolescents from grade 1, 93 from grade 2, and 94 - attending grade 3 . Among the total number of respondents, $52.3 \%$ were boys and $47.7 \%$ girls. The adolescents participating in the study were aged $13-17$. It should be emphasized that in one grade class there may be children at various ages, which results from the age at starting education, as well as repetition of the class due to failure at school.

\section{Research ethics}

Permission of school directors to conduct research in their organization was obtained. The personal consent of the informers to participate in the study was sought. Researchers have pledged that study participants will not disclose information related to the organization and informant. The rules of anonymity, volunteering and kindness were observed. Young people became acquainted with the purpose of research, questions and the importance of arguing reflection on their experience 


\section{Analysis of research results}

Aggression most often they concern peer contacts, aggressive behaviours towards adults, including teachers. Cases of aggressive and violent behaviour include $78 \%$ of junior high school students surveyed. Considering the occurrence of peer violence, the difference is visible when taking into account the gender variable. Among boys, more often $(89.1 \%)$ than among girls $(65.9 \%)$ various types of acts of aggression are observed. Also, more often, they are the perpetrators of violence (34.2\%). The authors also point to the coexistence of violent behaviour among peers. Disturbing is the fact that students $(24 \%)$ indicate that they experience several types of aggression at the same time. It follows that young people repeatedly reach for strength solutions to their problems. It can be concluded that the phenomenon of aggression is related not only to the lack of conflict-solving skills among the respondents, but also to the way of unloading the accumulated emotions (Dubis 2012, p. 94, 2014 p. 89).

Violence at school manifests itself not only in peer relations, but also in student-teacher relations and teacher-student, $67.8 \%$ of respondents declare that they had different kinds of conflicts with teachers. Over $11 \%$ of respondents admit to being aggressive towards teachers. Among aggressive behaviours towards teachers ignoring commands is the most frequent $(72.4 \%)$ which hinders running classes and deliberately provoking a teacher's anger $(51 \%)$. The purpose of such behaviour is to check the teacher's endurance and lose control over his / her behaviour. Sometimes students succeed and teachers react with aggressive behaviour towards students. Over 53\% of respondents indicate that teachers are aggressive towards them. This is most often psychological aggression $(96.5 \%)$ in the form of ridicule, humiliation, threats, and insults. It is very alarming that $11.5 \%$ of the surveyed students point to physical aggression in the form of jerking and pushing by the teachers. It should be emphasized that the source of frustration in the interactions between teachers and students are often conflicting interests and aspirations of both parties. Often there is a difference in the perception of the situation by the teacher and student, which can become a source of misunderstanding. Cases of teacher violence against students usually occur when teachers are unable to cope with inappropriate student behaviour. It is difficult for teachers to admit that they experience the lack of respect, and they prefer to solve the situation on their own as they can.

In research inquiries, M. Dubis (2014) the aim was to learn how students react to aggressive acts against them. Out of the total, over $41 \%$ of adolescents, to whom other students commit violence, try to talk and explain the situation, and $33.5 \%$ think that it is best to evacuate from the place at risk. A lot of respondents $(34.7 \%)$ take matters into their own hands according to 
the "eye for an eye" principle, defending themselves by returning and beating an attacker.

To sum up, it must be stated that aggression and violence occurring in the researched schools is an inseparable element of school life, which both students and teachers are used to. In addition, the significant scale of the phenomenon of aggression is probably connected not only with the lack of the ability to resolve conflicts among the respondents, but also with the way of unloading the accumulated emotions.

\section{Conclusion}

Violence and aggression at school have become a more common phenomenon. Numerous empirical studies and studies included in pedagogical publications testify its growth. On school grounds, the most common manifestations of aggression are: vandalism - destruction and devastation of school equipment, beatings, thefts, profanity, extortion, threats, interruptions in conducting lessons, intentional lies, provocations. These acts cannot be completely eliminated, but they can be and must be reduced.

One cannot look indifferently at them because the students become not only victims of aggression, but also aggressors. The school must stop treating aggression and violence with embarrassment, shame, helplessness and the tendency to hide facts. The solution to the problem of aggression at school requires intensification of educational activities, control of internal impulses and resolving conflicts without using force. Schools should therefore systematically diagnose pathological phenomena and apply remedies adequate to problems in a specific environment. Eliminating students' bad habits and replacing them with desirable forms of behaviour should be one of the main preventive tasks at school. It is teachers, educators and directors who are to take measures to reduce and prevent the extent of aggression and violence occurring at the school and increase resources to cope with the problems.

\section{References:}

1. Blachut J., Gaberle A., Krajewski K. (2006). Kryminologia. Gdansk: InfoTrade.

2. Borzucka- Sitkiewicz, K. (2010). Środowiskowe uwarunkowania agresywnych zachowań młodzieży.Katowice: SilesianUniversity Publishing.

3. Brzezinska, A. (2004). Jak rodzi się agresja? [In] Brzezińska, A. Hornowska, E. ed. Dzieci i młodzieżwobec agresji i przemocy. Warsaw: Scholar Publishing, pp. 107-123.

4. Czyz, E. (1996). Prawaucznia w szkole. Warsaw: Helsinki Foundation For Human Rights 
5. Dahleberg L., Krug E. (2002).Violence a global public health problem. [n] Krug, E. Dahleberg, L. Mercy, J. Zwi, A. Lozano, R. World Report on Violence and Health. Geneva, pp.1-19.

6. Danilewska, J. (2004). Agresja u dzieci - szkoła porozumienia. Warsaw: WSiP

7. Dabrowska-Bak, M. (1987). Przemoc w szkole. Warsaw, Pedagogy Quaterly, no 2

8. Dabrowska-Bak, M., Pawełek K. (2014). Opresja w szkole. Warsaw: Academic Publishing Żak.

9. Dombach, E. K. ( 2003). Mobbing w szkole. Jak zapobiegać przemocy grupowej. Gdansk: GWP.

10. Dubis, M. (2004). Violence and aggression in interpersonal contacts at school. [In.]. Ludikova, L. Magister, no 2 ,Olomuci: UniversityPalckeho, pp. 70-94.

11. Dubis, M. (2010). Wspótpraca szkoły z policją w zakresie profilaktyki zachowań agresywnych umłodzieży. [In] Moczuk, E. Sagan, B. ed. Ius et administratio. Rzeszow: Specialnotebook - 2nd Sociologists' ForumPrawo $i$ lad społeczny, pp. 162-186.

12. Dubis, M. (2012). Zachowania agresywne $w$ szkole w okresie adolescencji.[In] Rajchel, K. ed. Scientific PapersNo 1(18) Warsaw: WSIZiA, p. 84-97.

13. Dubis, M., (2014). Poczucie bezpieczeństwa gimnazjalistów w szkole [In] Rajchel, K. Scientfic Papers2(27), Warsaw: WSIZiA, pp. 86-99.

14. Dubis, M., Karbowniczek, J. (2015). Młodzież jako wartość $w$ nauczaniu Jana Pawta II.[ Lisnik,. A. Ambrozy, K. M. ed. Sociálneposolstvo Jána Pavla II. prednešnýsvet „,1989 a 25 rokov po... Ruzomberok: Verbum, Ružomberok, pp.262- 271.

15. Dubis, M. (2016).Pedagogiczne uwarunkowania agresji dzieci $i$ młodzieży. Rodzina - Szkoła -Cyberprzestrzeń - Uzależnienia. Lublin: Inovatio Press.

16. Fraczek, A. (1996). Agresja i przemoc wśród dzieci i młodzieży jako zjawisko społeczne.[In] Fraczek, A. Pufal, I. ed. Agresja wśród dzieci i młodzieży, Kielce: ZNP Publishing

17. Grzywa -Bilkiewicz, A.(2006). Problem agresji we współczesnej szkole. [In] Muchacka B. ed. Szkoła w nauce i praktyce edukacyjnej, Cracow: Impuls Publishing, pp. 187-199.

18. Guerin, S. (2004). Przemoc i prześladowanie w szkole. Skuteczne przeciwdziałanie agresji wśródmłodzieży. Gdansk: GWP. 
19. Karbowniczek,J. (2011). Rola i znaczenie mass mediów w życiu dziecka. [In] Kostelansky, A. ed.Implementacia Medialnejvychovy do edukacie v primarnom vzdelavani. Ruzoberok: Verbum.

20. Karbowniczek, J., Okoński, A.(2012).Bridging the phenomena of social pathology as a form ofenhancing national security[In] Zatko, J. ed. Bezbednosna $i$ antikorupcijskapolitika v EvropskojUnii, Serbia: EEDA

21. Kirwil, L. (2004). Agresja szkolna jako rodzaj agresji proaktywnej, [In] Rejzner, A. ed. Agresja w szkole. Spojrzenie wieloaspektowe. Warsaw: TWP College of Education, pp. 7-25.

22. Kolodziejczyk, J. (2008). Agresja i przemoc w szkole. Konstruowanie programu przeciwdziałania agresji $i$ przemocy $w$ szkole. Cracow: NODN Sophia.

23. Komendant-Brodowska, A., Giza-Poleszuk, A.,Baczko-Dombi, A.(2011). Przemoc $w$ szkole. Raport $z$ badań, lipiec 2011,WarsawRetrieved on-line, access 28.11.2017.

24. Kowal, P. (2012). Przemoc i agresja w świecie nowoczesnych mediów, [In]. Bebas, S., Plis, J., Bednarek, J.ed. Patologie w cyberświecie, Radom: Higher School of Commerce, $p p$. 287-298.

25. Krahe, B. (2005). Agresja, Gdansk: GWP

26. Libiszowska-Zoltkowska, M. (2008). Agresja - słowo wstepne.[In] Libiszowska-Zoltkowska, M. Ostrowska, K. ed. Agresja w szkole. Diagnoza i profilaktyka, Warsaw:Difin, pp. 3-8.

27. Makaruk, K. (2017). Przemoc rówieśnicza, [In] Dziecko krzywdzone. Teoria i praktyka, Vol. 16, no 1, Warsaw.

28. Mannheim, K. ( 2011). Problem młodzieży w nowoczesnym społeczeństwie. [In] Szafraniec, K. Młodzież jako problem i wyzwanie ponowoczesności, Torun: Adam Marszałek Publishing.

29. Milkowska-Olejniczak, G. (2003). Agresja.[In] Pilch, T. ed. Encyklopedia pedagogiczna XXI wieku, Warsaw:Academic Publishing Zak

30. Moczuk, E. (2015). Młodzież Miasta Rzeszowa wobec problematyki przemocy $w$ szkole, używania środków psychoaktywnych i uzależnień behawioralnych. Rzeszow: Abrys.

31. Okon, W. (2017). Nowy stownik Pedagogiczny, Warsaw: Academic Publishing Zak

Olweus, D. (2007).Mobbing, Fala przemocy w szkole. Jak ja powstrzymać?. Warsaw: Czarna Owca Publishing.

32. Ostrowska, K., Surzykiewicz, J. (2005).Zachowania agresywne w szkole. Badania porównawcze 1997 i 2003. Warsaw, Medical Center for Psychological and Pedagogical Support. 
33. Pakulniewicz, W. (2010). Agresja i przemoc w szkole. Jak radzić sobie $z$ przejawami niepożadanych zachowań uczniów. Warsaw: Oświata Publishing Group.

34. Peret-Drazewska, P. (2014), Współczesna młodzież postrzegana z perspektywy rówieśników. Studiumteoretyczno-empiryczne, Poznan: Scientific Publishing UAM.

35. Portman, R. (2006). Przemoc wśród dzieci. Uchwycic sedno, Kielce: Jedność Publishing.

36. Pospiszyl, I. (1999). Razem przeciw przemocy, Warsaw: Academic Publishing Zak.

37. Przewlocka, J. (2015).Bezpieczeństwo uczniów i klimat społeczny $w$ polskich szkołach. Warsaw:IBE.

38. Pufal-Struzik, I.(2007). Agresja i przemoc $w$ szkole. Przyczyny, rozpoznawanie, zapobieganie.

39. Kielce: Pedagogic Publishing ZNP.

40. Rigby, K. (1997). Bullying in schools - And what to do about it. London and Philadelphia: Jessica Kingsley Publishers Ltd

41. Rigby, K. (2002). New Perspectives on Bullying. London: Jessica Kingsley Publishers Ltd

42. Schneider, H. J. (1997). Przemoc $w$ instytucjach [In] Hołyst, B. ed. Przemoc $w$ życiu codziennym.Warsaw: CB Andrzej Zasieczny, pp. 121-136.

43. Surzykiewicz, J. (2000). Agresja i przemoc w szkole. Uwarunkowania socjoekologiczne, Warsaw: Medical Center for Psychological and Pedagogical Support.

44. Szpringe,r M. (2004). Profilaktyka społeczna. Rodzina. Szkoła. Środowisko lokalne. Kielce: Swietokrzyska Academy Publishing

45. Tatarowicz, J. (1998). Agresja i przemoc w badaniach oświatowych. [In] Ostrowska, K. Tatarowicz, J. ed. Agresja $w$ szkołach polskich $i$ niemieckich. Warsaw: Medical Center for Psychological and Pedagogical Support, MEN, pp. 79-85.

46. Wojciszke, B. (2003). Relacje interpersonalne, [In] Strelau, J. ed. Psychologia. Podręcznik akademicki, Gdansk: GWP, pp. 147-186.

47. Wolinska, M.J. (2003). Agresywność młodzieży. Problem indywidualny i społeczny. Lublin: UMCS Publishing. 